\title{
Low-Level Laser Therapy in Russia: History, Science and Practice
}

\author{
Sergey Vladimirovich Moskvin* \\ State Scientific Center of Laser Medicine, Russia, Moscow
}

\section{*Correspondence to}

Sergey Vladimirovich Moskvin

Doctor of Biological Sciences, Candidate of Engineering Sciences Leading Researcher: State Scientific Center of Laser Medicine, Moscow, Russia

Tel: +7-905-7701860

Fax: +7-499-2505544;

Email: 7652612@mail.ru

Published online 28 March 2017

\begin{abstract}
In Russia (formerly USSR) study of biomodulation action (BMA) mechanisms of lowintensity laser irradiation (LILI) began in 1964, immediately after the development of lasers. During the period from 1965 to 1972 several dozens of scientific conferences were held, hundreds of studies were published. Generally, secondary mechanisms and results of LILI effect on patients with various diseases were studied. This data was immediately implemented into practical medicine in the fields of oncology, surgery, dermatology and dentistry, and since 1974 low level laser therapy (LLLT) is included in the standard of state medical care. For 50 years no less than 1000 books were published (monographs, collections, methodical and clinical materials), thousands of researches were carried out. Primary mechanism and patterns of interaction of LILI with acceptors within cells can be represented in the following order: absorption of photon's energy - emergence of a local temperature gradient - release of $\mathrm{Ca}^{2+}$ from intracellular stores - stimulating $\mathrm{Ca}^{2+}$-dependent processes. Understanding of this process allowed the explanation of all known secondary effects, optimized methods and extremely increased effectiveness of LLLT. Owing to the knowledge of BMA mechanisms of LILI, numerous associated and combined LLLT techniques were developed and are widely used nowadays: locally, on the projection of internal organs, laser acupuncture, reflexology, intracavitary, transdermal and intravenous laser blood illumination, magnetic-laser therapy, laser phoresis, laser-vacuum massage, biomodulation, etc. About 400000 laser therapeutic devices are used in Russian practical healthcare. Unique, having no analogues in the world devices, are produced - red pulsed laser diodes (wavelength $635 \mathrm{~nm}$, power 5-40 W, pulse duration $100 \mathrm{ns,}$ frequency $10000 \mathrm{~Hz}$ ) are designed specially for effective laser therapy.
\end{abstract}

Keywords: Low-level laser therapy; Laser biomodulation; Mechanisms and methods; Russia.

\section{Introduction}

Until recently laser therapy was ignored in some countries, especially in Western Europe and the United States, it was considered that its effectiveness was not proven, there was little reliable research, mechanisms were not known, etc. Only at the beginning of the 21 st century attitude toward low level laser therapy (LLLT) has changed, it was clearly shown that negative studies on LLLT were results of a wrong set of parameters, conclusions of these negative studies are quoted often while some read only abstracts, without scrutinizing a publication carefully. ${ }^{1}$ LLLT has been applied in clinical practice since the 80 's of the last century in many countries: Japan, ${ }^{2}$ China, ${ }^{3}$ Canada, ${ }^{4}$ Northern Ireland, ${ }^{5}$ Vietnam, ${ }^{6}$ Latin America and Eastern Europe. ${ }^{7}$ However, this highly effective method of treatment was never as widespread as in Russia. ${ }^{8,9}$

The basic of LLLT is so-called biostimulating or biomodulating effect of low-intensity laser irradiation (LILI) that was found in numerous studies in the 70's of the last century (Table 1).

However, the era of laser therapy literally began long before the development of lasers themselves. Therapeutic properties of "concentrated" light, lamp (e.g. UV, blue or red) isolated by narrow part light filter from total spectral irradiation range were known already in the 19th century. This discovery formed the basis for a new field of medicine - light- or phototherapy, and in 1903 N.R. Finsen was awarded Nobel Prize "in recognition of his contribution to the treatment of diseases, especially lupus vulgaris, with concentrated light radiation, whereby he opened a new avenue for medical science." ${ }^{29}$ All researchers of that time were convinced that to improve effectiveness of phototherapy it was necessary to meet the following conditions: decrease width of the spectral range to the limit and set optimal light capacity, contacted area, exposure. ${ }^{30-37}$

The main property of laser light is its monochromatici- 
Table 1. Chronology of the Development of Laser Sources and the First Studies of Biologically Significant Effect of LILI

\begin{tabular}{|c|c|c|c|c|}
\hline Laser Type & Wavelength, nm & $\begin{array}{l}\text { Year } \\
\text { [Reference] }\end{array}$ & Effect & Reference \\
\hline Ruby & 694 & $1960^{10}$ & $\begin{array}{l}\text { Healing of purulent wounds, immune } \\
\text { system activation, endothelial cell } \\
\text { proliferation }\end{array}$ & $11,12,13,14$ \\
\hline Nd:YAG & 1064 & $1964^{15}$ & Proliferation, collagen synthesis in vitro & 16,17 \\
\hline Nd:YAG (KTP) & 532 & $1963^{18}$ & $\begin{array}{l}\text { Hemoglobin oxygenation in red blood } \\
\text { cells in vitro }\end{array}$ & 19 \\
\hline $\mathrm{CO}_{2}$ & 10600 & $1964^{20}$ & Healing of purulent wounds & 21,22 \\
\hline $\begin{array}{l}\text { Helium-Neon } \\
(\mathrm{He}-\mathrm{Ne})\end{array}$ & $\begin{array}{l}633 \text { (basic), 544; 594; } \\
612 ; 1152 ; 1520 ; \\
3391 \text { (rarely used) }\end{array}$ & $1960^{23}$ & Erythropoiesis & 24,25 \\
\hline $\begin{array}{l}\text { Helium-cadmium } \\
\text { (He-Cd) }\end{array}$ & 442 & $1968^{26}$ & $\begin{array}{l}\text { Changes in systemic and regional } \\
\text { hemodynamics }\end{array}$ & 27 \\
\hline $\begin{array}{l}\text { Semiconductor } \\
\text { (diode) }\end{array}$ & $300-9000$ & $1962^{28}$ & $\begin{array}{l}\text { Proliferation, activation of } \\
\text { microcirculation, anti-inflammatory } \\
\text { action, immunomodulatory effect, } \\
\text { anesthetization, effects on blood }\end{array}$ & $\begin{array}{l}\text { Many publications in different } \\
\text { countries. Most frequently used LILI } \\
\text { wavelength } 405,445,525,635, \\
785,808,830,904 \text { and } 1300 \mathrm{~nm}\end{array}$ \\
\hline
\end{tabular}

ty, i.e. extremely narrow spectral area (line). This determines its higher efficiency compared with filtered light of a lamp. Moreover, it is much easier to set and control energy of laser light, allocate it over the surface and deliver to the required location without loss than to do the same with an average lamp with a filter. Lasers appeared to be not only convenient but also a fundamentally more effective instrument of therapeutic effect than other light sources, which determined the emergence and development of a qualitatively new direction of phototherapy laser therapy. ${ }^{38}$

\section{History of Laser Therapy Development in Russia}

In Russia (formerly USSR) study of biomodulation action (BMA) mechanisms of LILI began in 1964, immediately after the development of lasers. During the period from 1965 to 1972 several dozens of scientific conferences were held, hundreds of studies were published. Generally, secondary mechanisms and results of LILI effect on patients with various diseases were studied. This data was immediately implemented into practical medicine in the fields of oncology, surgery, dermatology and dentistry, and since 1974 LLLT is included in the standard of state medical care. For 50 years no less than 1000 books were published (monographs, collections, methodical and clinical materials), thousands of researches were carried out. From 1981 to present, fundamental research in the field of primary mechanisms of laser biomodulation, the results of which are known all over the world, is conducted in Moscow (ILIT RAS) managed by prof. T.J. Karu.

Primary mechanism and patterns of interaction of LILI with acceptors within cells can be represented in the following order: absorption of photon's energy - emergence of a local temperature gradient - release of $\mathrm{Ca}^{2+}$ from intracellular stores - stimulating $\mathrm{Ca}^{2+}$-dependent processes. Understanding of this process allowed the explanation of all known secondary effects, optimized methods and ex- tremely increased effectiveness of LLLT. ${ }^{39-41}$

Highly effective LLLT techniques are designed and widely used: locally, on the projection of internal organs, laser acupuncture, reflexology, intracavitary, transdermal and intravenous laser blood illumination, etc. Associated and combined techniques are being actively developed: magnetic-laser therapy, laser phoresis, laser-vacuum massage, etc. The principles of combining LLLT with taking medicine were developed; the problems of antibiotic resistance, allergization, etc. are being successfully solved. Multi-frequency modulation modes of LILI are of particular interest: "biosynchronization" with patient's biorhythms, LASMIK ${ }^{\circledR}$, etc.

About 400000 laser therapeutic devices are used in Russian practical healthcare; about half of them are used in professional medicine (clinics), and half of them - at patients' home for independent use. Around the world only lasers designed for other purposes (technical) are used, which are not always effective in medicine. The peculiarity of Russian laser therapeutic apparatus is the development and production of special lasers, designed specifically for therapy. For example, unique, having no analogues in the world, devices are produced - red pulsed laser diodes (wavelength $635 \mathrm{~nm}$, power 5-40 W, pulse duration $100 \mathrm{~ns}$, frequency $10000 \mathrm{~Hz}$ ) are designed specially for effective laser therapy. ${ }^{42}$ Laser therapy is widely used in almost all medicine fields: obstetrics and gynecology, gastroenterology, cardiology, dermatology and cosmetology, neurology, oncology, otolaryngology, pediatrics, pulmonology, dentistry, traumatology and orthopedics (diseases of musculoskeletal system), urology and andrology, phthisiology, etc.

\section{Mechanisms of Biological (Therapeutic) Action of Low-Intensity Laser Light}

LILI is a stream of the same photons as in other light sources, but has only one energy (or wavelength). There- 
fore, the effect of laser light on living patterns seems to obey the laws of classical photobiology, however, laser-induced bioeffects are fundamentally different from the known responses.

Photobiological processes can be schematically represented in the following sequence: acceptors, absorption spectrum of which coincides with incident light wavelength, absorbed photons then activate and trigger biochemical or physiological responses that are typical (specific) for these absorbing elements. If we consider laser-induced bioeffects, it seems that there are no specific acceptors and responses of biological system (cell, organ, organism), interaction is entirely non-specific. Let us try to understand the nature of this feature.

To demonstrate existing differences in processes (responses) that occur as a result of absorption of laser (monochromatic) and ordinary light let us consider as an example a special case of photobiology - photosynthesis, in which activation of photosynthetic pigments by light starts the process of formation of organic substances from carbon dioxide and water. All absorbing acceptors, providing photosynthesis, "work" only in visible part of the spectrum that is $400-700 \mathrm{~nm}$. This is so-called action spectrum, i.e. wavelength range in which the effect is observed. For other spectral ranges, light energy absorption by acceptors is excluded. Will photosynthesis occur when plants are irradiated by infra-red (IR) lamp? No! The second response is continuously growing with saturation, result depending on magnitude of absorbed energy, - the more sunlight there is, the more active photosynthesis is and the more biomass there is (if there are nutrients and water). The light curves of photosynthesis were first received in 1884 by K.A. Timirjazev (Figure 1). If you reduce the intensity of light at $10^{4}-10^{6}$ times, i.e. it is almost dark, will photosynthesis occur? Of course not! However, everything is different when LILI interacts with biological systems.

The first thing that surprises is lack of action spectrum in case of laser modulation. This statement requires explanation. Of course, depending on the chosen model of study, e.g. cell type or tissue, investigated effect, localization effects (in vitro or in vivo), "action spectrum" is observed, this is a fairly well known fact. ${ }^{43-46}$ There are a lot of similar studies, but they do not clarify the situation, but even confuse, because action spectra vary significantly depending on experimental conditions, which does not allow marking out only one specific acting factor (acceptor). If we consider the issue in detail, we can find out the following facts.

First, responses "wavelength - effect" are found only for some parameters of one experiment model. If we consider an integral response of a biological system at laser impact, it becomes clear that absorption by a whole cell is important but not a selective absorption of any component of a living cell, which everyone is unsuccessfully searching for many years. It is not so important, what kind of intracellular structure absorbs, but definitely the fact that absorption is required.
Well-known works show significantly different action spectra for some of intermediate stages of culture HeLa cell cycle: DNA and RNA synthesis, adhesion, but their united spectra characterizing the whole division process, corresponds to the absorption of a cell as a whole (Figure 2). ${ }^{46-49}$ However, it is impossible to conclude on the basis of the received spectra $(614-624,668-684,751-772$ and $813-846 \mathrm{~nm}$ ) that there is a universal cellular mechanism of biomodeling action of LILI, ${ }^{49-51}$ we can only talk about the patterns of interaction between laser light and HeLa cells. Moreover, these spectra cannot be recommended for clinical practice, ${ }^{45,52}$ because clinical effectiveness of LLLT with such parameters is not confirmed. ${ }^{53,54}$

Secondly, analysis of literature has shown that in experimental and clinical studies, successful (to a variable degree) results of biomodulatory LLLT effect are obtained at more than 100 (!) wavelengths in the range of 248 to $10600 \mathrm{~nm} .{ }^{41}$ The size of the article does not allow presenting all references in literary sources and summary tables of studies, in vitro and in vivo; we can only represent an overall picture schematically on a logarithmic scale (Figure 3). Analysis of available materials and own research experience definitely confirm a simple rule: the less absorption is, the more power density (PD) must be. If optimal space and energy LILI parameters are ensured, the effect can be achieved to some degree in any experiment with a laser source in all spectral ranges. Besides, the more complex a biological system is, the easier it is to get a positive response to laser irradiation.

It is absolutely impossible that action spectrum is absent in photobiology, e.g. photosynthesis occurs only in visible spectrum (400-700 nm). But laser light successfully provokes similar effects, such as increase of biomass or increase of cell proliferation for different cells and in a very wide wavelength range that matches the absorption spectrum of cells or tissues. Since molecules and molecular complexes have quite a narrow absorption band, each of them cannot act as the only absorbing element (acceptor), but rather absorb all in aggregate, also water, as we know, has no transmission windows. ${ }^{55}$ This is what lack of a spe-

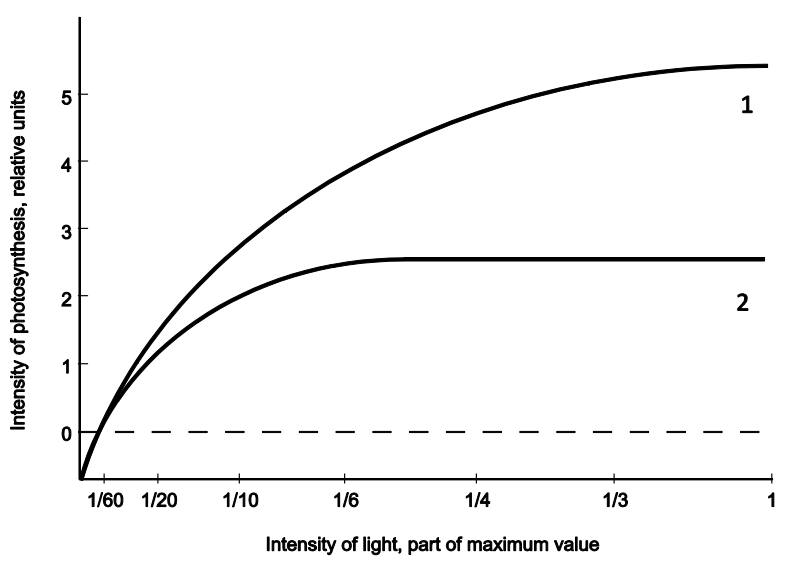

Figure 1. Change of Intensity of Light (1) and Shadow (2) Photosynthesis of Plants Depending on Illumination. 


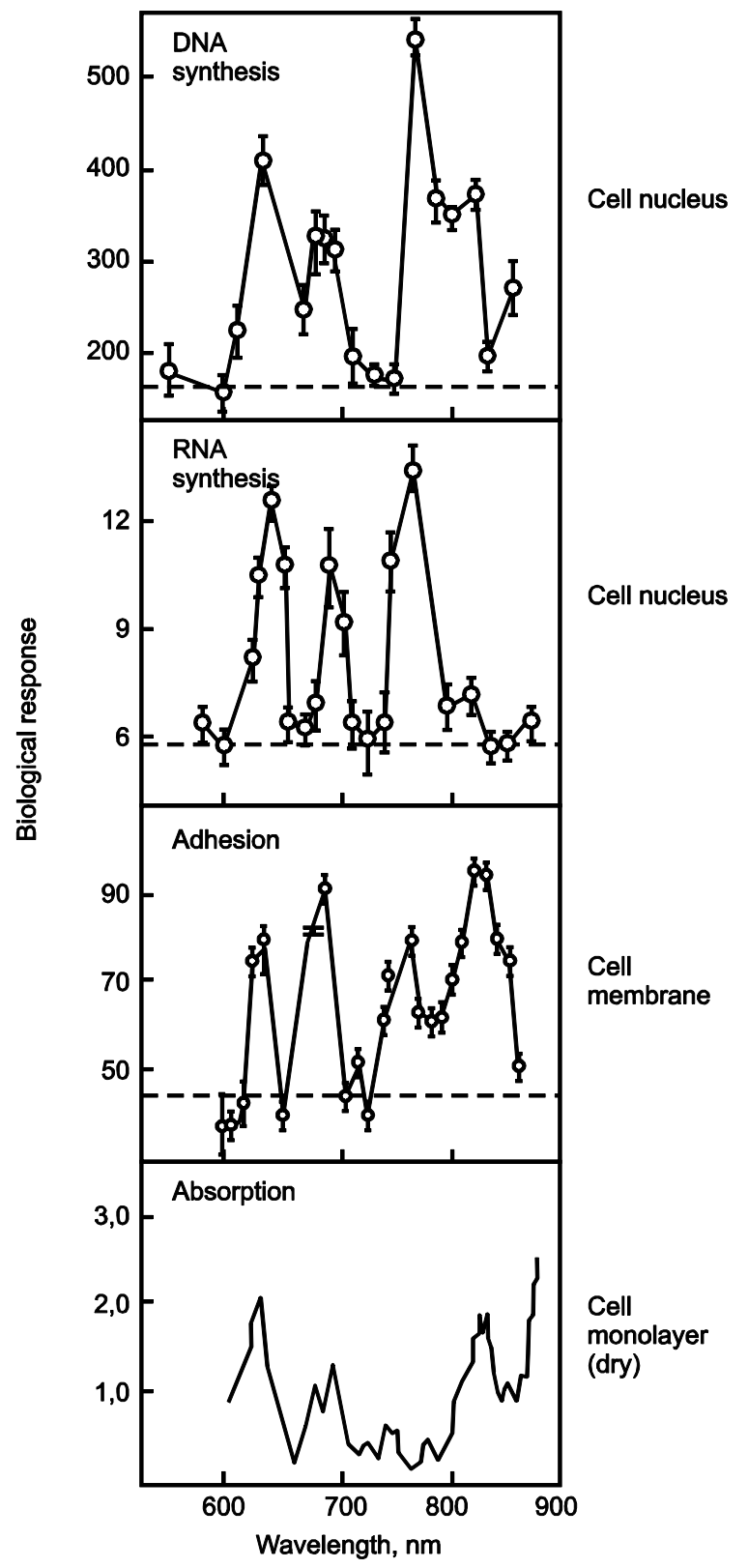

Figure 2. Action Spectra for Different Biological Effects, Hela Cell, Optimal Energy Density $-0.01 \mathrm{~J} / \mathrm{cm}^{2} .{ }^{46-49}$

cific action spectrum is and we can explain this fact only by the thermodynamic nature of LILI interaction with a living cell, when effecting on absorbing centers, temperature gradient causes a trigger launch of the physiological regulation system, which are, as we assume, intracellular calcium stores that can release $\mathrm{Ca}^{2+}$ under the influence of many external factors ${ }^{56}$. There are enough arguments in confirmation of our theory, however, due to the limited size of the article, we present only one - all the known effects of laser-induced biomodulation are secondary and $\mathrm{Ca}^{2+}$-dependent ${ }^{39,40}$ !

Energy responses are even more surprising than spectral regularities. Let us review some basic concepts and fundamentals, laser therapy "axioms."

For an effective impact of LILI, it is necessary to provide optimum power and PD, i.e. distribution of light energy over the area of cells in vitro and area and/or volume of tissues in animal experiments and clinical settings.

Exposure time to one area is important, which needs to be strictly in the range of 100-300 s (1.5-5 minutes), except for methods like acupuncture (20-40 seconds) and intravenous laser irradiation of blood (up to 20 minutes). As a result we receive PD per time unit or energy density (ED). For pulsed lasers (pulse duration of 100-150 ns), when frequency increases, the average power increases proportionally, that is ED effect.

The most well-known energy response of biomodulating LILI action is the presence of optimum dependencies "ED-effect," sometimes called "biphasic." ${ }^{77}$ Let us cite two experimental graphs as an example, that have also other interesting features (Figures 4 and 5). ${ }^{58,59}$ Similar effect is certainly not observed in photobiology (see Figure 1).

The first graph (Figure 4) is interesting in that ED (0.1 J/ $\mathrm{cm}^{2)}$ for pulsed lasers is ten times less than for continuous lasers and also for IR spectrum $\left(20 \mathrm{~J} / \mathrm{cm}^{2}\right)$ in a similar experimental model (E. coli proliferation) ${ }^{60}$ which indicates greater efficiency of pulsed mode. There is no analogue of this effect in photobiology.

The second graph (Figure 5) is also on E. coli with continuous lasers $(633,1064$ and $1286 \mathrm{~nm})$, and the study is unique by its demonstration of the second efficiency peak, while ED is decreased $10^{4}$ times. Based on previous research we can assume that when power is decreased $10^{6}$ times, laser-induced effect will also be observed. What is the answer to the rhetorical question about the possibility of photosynthesis in the dark (see Figure 1)?

I would like to mention another interesting and important response of laser modulation - nonlinear dependence on exposure time, which is easily explained by waves frequency of increased $\mathrm{Ca}^{2+}$ concentration, that spread in cytosol after activation of intracellular calcium stores. And these periods are identical for completely different types of cells, and are strictly 100 and 300 seconds (Table 2). Clinical studies prove the effectiveness of such exposure
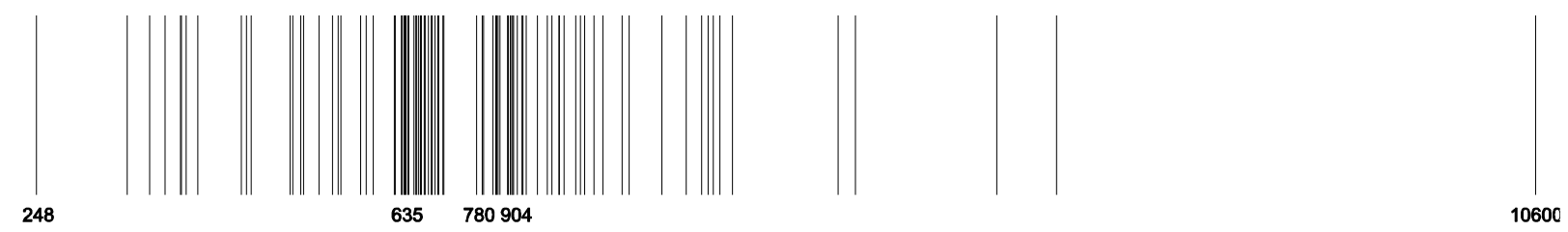

Figure 3. Wavelengths Spectrum (Logarithmic Scale, Line Width Conditionally Corresponds to $1 \mathrm{~nm}$ ) at Which Biological Effects Were Received. 


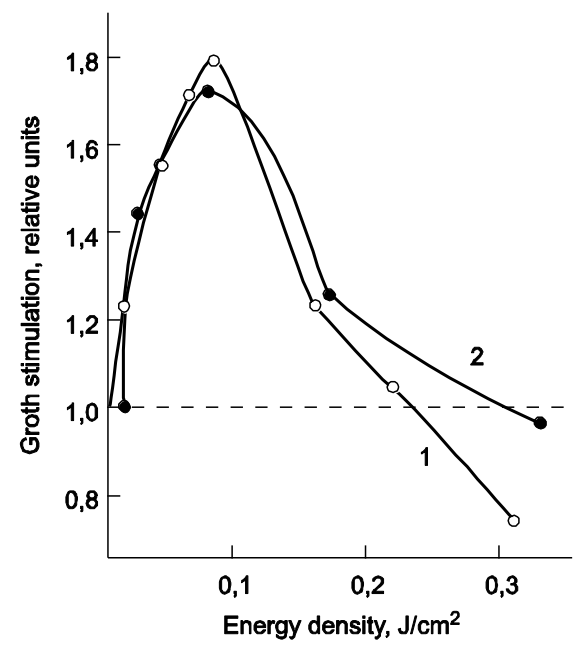

Figure 4. Dependence of Escherichia coli Growth Stimulation From ED of Infrared LILI, Pulsed Semiconductor Laser, Wavelength $890 \mathrm{~nm}$, Pulse Repetition Frequency $3480 \mathrm{~Hz}(1)$ and $666 \mathrm{~Hz}(2)$. A dotted line indicates control level..$^{58}$

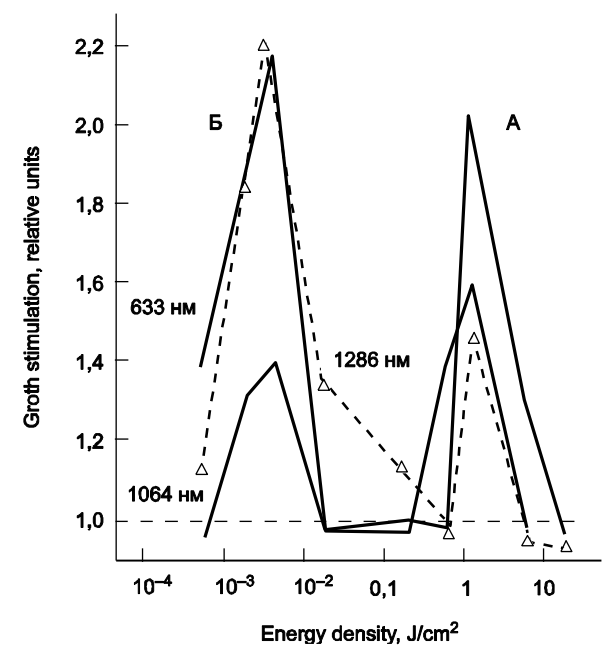

Figure 5. Dependence of Escherichia coli Growth Stimulation From ED at An Identical Density Intensity $\left(15,7 \mathrm{~mW} / \mathrm{cm}^{2}\right)$ at Different Wavelengths $(633,1064$ and $1286 \mathrm{~nm}) .^{59}$

to hundred times superior. Please also note that the effect is observed in a very wide range of wavelengths.

Let us show graphs of one study for visual demonstration that activation of mitochondria is a secondary work process, a result of increasing $\mathrm{Ca}^{2+}$ concentration in cytosol (Figure 6). ${ }^{73}$

The most important fact is that increase of $\mathrm{Ca}^{2+}$ concentration occurs only from intracellular stores (where it is again deposited after physiological cycle in 5-6 minutes), and not due to ions entering from outside, as many scientists consider ${ }^{74-79}$ First, there is no correlation between ATP level in cells and outside transport of $\mathrm{Ca}^{2+}$ into a cell, mitochondrial activation is performed only by increasing $\mathrm{Ca}^{2+}$ concentration from intracellular stores. ${ }^{80,81}$ Secondly, removal of calcium ions from serum does not delay increase of $\mathrm{Ca}^{2+}$ concentration in cell cycle anaphase, ${ }^{82}$ i.e.

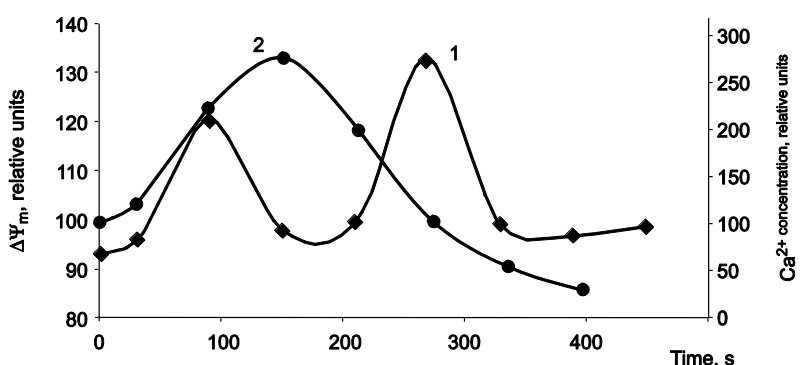

Figure 6. Changes of $\mathrm{Ca}^{2+}$ Concentration (1) in Cytosol and Mitochondria Redox Potential $\Delta \Psi_{m}$ (2) After Laser Stimulation (647 $\mathrm{nm}, 0,1 \mathrm{~mW} / \mathrm{cm}^{2}$, Exposure $15 \mathrm{~s}$ ) on Human Foreskin Fibroblasts. $^{73}$

activation of cell proliferation by LILI action is absolutely disconnected with extracellular calcium, membranes, specifically dependent pumps and etc.

All these responses can be easily explained if we represent mechanisms of laser BMA in the following sequence: as a result of LILI a temperature gradient occur inside a cell and there is a short-time increase in concentration of calcium ions $\left(\mathrm{Ca}^{2+}\right)$ released from intracellular stores, with development of cascade of organism responses to an external effect: work of immune and vascular systems normalizes, metabolic and proliferative processes are activated, there is analgesic effect and etc. (Figure 7). ${ }^{39-41}$ All biological effects are $\mathrm{Ca}^{2+}$-dependent, nonlinear response "ED-effect" and "exposure-effect" can be explained by peculiarities of intracellular calcium stores work, lack of spectrum can be explained by its nonspecific inclusion. The above information refers to "laser-", rather than "photo-" (biomodulation), that is to monochromatic light and in absence of specific impact.

Proper understanding of mechanisms of LILI biomodulating action allowed to work out recommendations for effective laser therapy application and laid basis for development of new techniques.

\section{Requirements for Protocols of Laser Therapy Treatment in Russia, Laser Therapy Methods}

These protocol requirements are obligatory, as it is proved that all parameters of listed below methods must be set. If even one of the parameters is incorrect, predictable and appropriate response to laser light and desired therapeutic effect cannot be achieved.

Most Russian devices have $1 \mathrm{M}$ or $2 \mathrm{M}$ class of laser danger according to IEC 60825-1:2007, while foreign devices have mainly $3 \mathrm{R}$ class of laser danger, and this greatly complicates their operation. Moreover, in most cases minimum LILI energy is required for successful laser therapy techniques, and increase in power and exposure (energy) leads to inhibitory effect, this is a well-known fact. ${ }^{11,83}$

All laser therapy techniques must contain the following information.

1. Wavelength of laser light is measured in nanometers $[\mathrm{nm}]$. The most common wavelengths in laser therapy are:

- 365-405 nm - ultraviolet (UV) spectrum, 
Table 2. Optimal Exposure of 100 or 300 Seconds for Maximum Effect In Vitro

\begin{tabular}{llll}
\hline Cell Type & Result & Wavelength, nm & Reference \\
\hline E. coli, S. aureus & Proliferation & 467 & 61 \\
Hippocampus & Epileptiform activity & 488 & 62 \\
Fibroblasts & Proliferation & 633 & 63 \\
Fibroblasts & Increase of Ca ${ }^{2+}$ Concentration & 633 & 64,65 \\
Keratinocytes & Increase of IL-1a and IL-8 production and mRNA expression & 633 & 66 \\
Macrophages & Proliferation & 633 & 67 \\
Fibroblasts, E. coli & Proliferation & 660 & 68 \\
Human neutrophils & Increase of Ca ${ }^{2+}$ Concentration in cytosol & 612 & 69 \\
Cells of human buccal epithelium & Proliferation & 812 & 70 \\
E. coli & Proliferation & 890 & 58 \\
Myoblasts C2C12 & Proliferation, viability & 660,780 & 71 \\
HeLa & Mitotic activity & $633,658,785$ & 72 \\
E. coli & Proliferation & $633,1064,1286$ & 59 \\
\hline
\end{tabular}

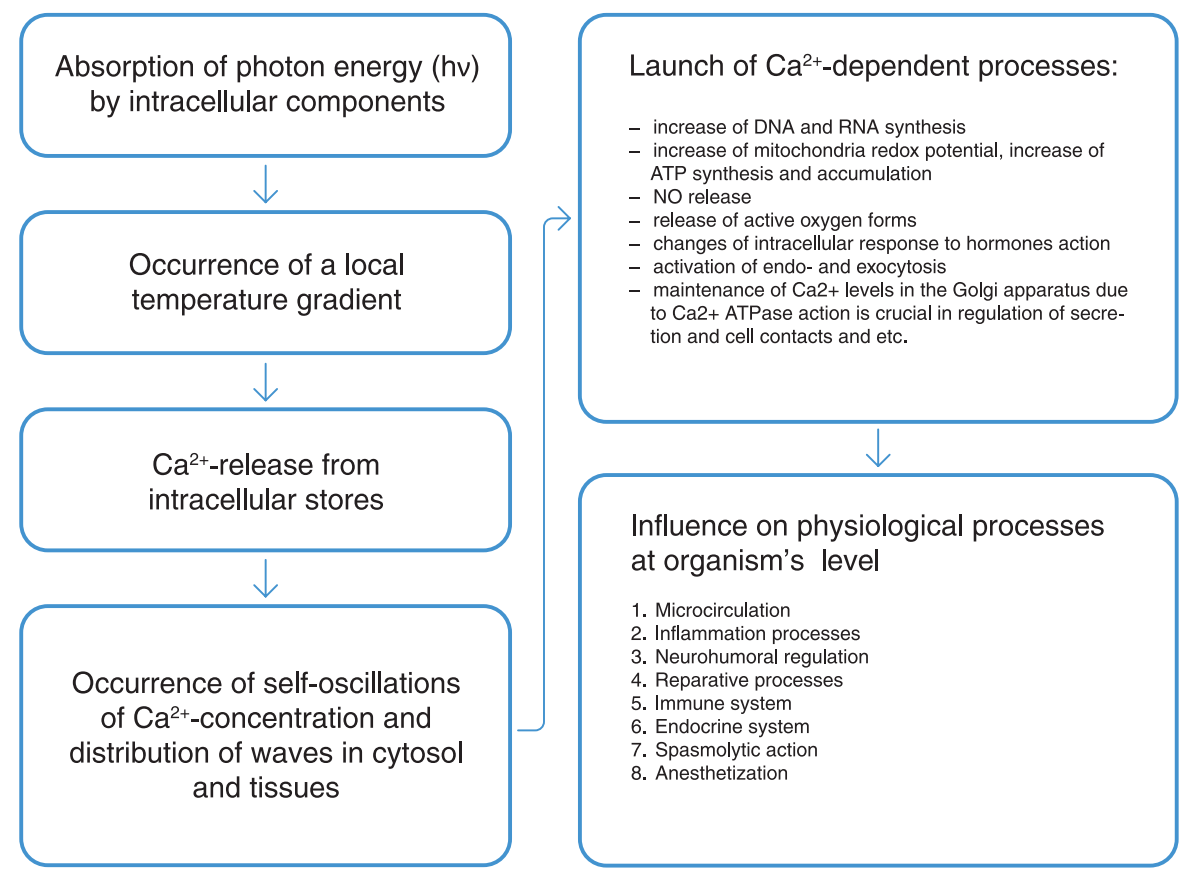

Figure 7. The Sequence of Biological Effects Following LILI Exposure (Mechanisms of Biological and Therapeutic Effect of LLLT)

- 440-445 $\mathrm{nm}$ - blue spectrum,

- $520-525 \mathrm{~nm}$ - green spectrum,

- $635 \mathrm{~nm}$ - red spectrum,

- 780-785 nm - infrared (IR) spectrum,

- $\quad 890-904 \mathrm{~nm}$ - IR spectrum.

It is not allowed to shine simultaneously laser and/or non-coherent light sources with different wavelength on one area due to inhibitory interaction.

2. Mode of laser operation: continuous, modulated, pulsed.

3. Radiation power of LILI.

Average power of continuous lasers operating in continuous or modulated modes is measured in milliwatts $(\mathrm{mW})$, impulse (peak) power of pulsed lasers is measured in watts $(\mathrm{W})$.

4. Modulation frequency or pulse repetition frequency for a pulsed mode - number of oscillations (pulses) per time unit (second) is measured in hertz $(\mathrm{Hz}, 1 / \mathrm{s})$.

5. An important parameter of pulsed lasers is duration of light pulse, which is a constant (usually only 100$150 \mathrm{~ns})$. Average power of pulsed lasers $\left(\mathrm{P}_{\mathrm{av}}\right)$ is directly proportional to pulsed power $(\mathrm{Pp})$, pulse duration $\left(\tau_{p}\right)$ and frequency $\left(F_{p}\right): P_{a v}=P_{p} \times \tau_{p} \times F_{p}$.

6. Illumination area is measured in square centimeters $\left(\mathrm{cm}^{2}\right)$.

Required area is almost always ensured by a technique without unnecessary measurements, e.g. in a contact-mirror technique area is supposed to be $1 \mathrm{~cm}^{2}$. Laser diodes in matrix emitters must be positioned so that impact area is multiplied by PD. For example, 8 (most often) pulsed laser diodes, $10 \mathrm{~W}$ each are placed on a surface area of 8 $\mathrm{cm}^{2}$ and skin contact PD is $10 \mathrm{~W} / \mathrm{cm}^{2}$ accordingly. During 
laser acupuncture or intravenous laser irradiation of blood (ILIB) area is not specified, because impact area is too small, and diffusion and absorption of laser light in volume of biological tissues is primary.

7. $\mathrm{PD}$ is measured in watts or milliwatts per square centimeter $\left(\mathrm{W} / \mathrm{cm}^{2}\right.$ or $\left.\mathrm{mW} / \mathrm{cm}^{2}\right)$.

8. Exposure (exposure time) on one area (zone) and total time of a treatment is measured in seconds (s) or minutes ( $\mathrm{min}$ ). Total time of laser therapy treatment (consistent effect on all areas) should not exceed 20 minutes, for one area - 5 minutes (except for intravenous laser irradiation of blood). This is a very important parameter that almost never can be changed.

9. Localization of impact (technique).

10. Number of procedures for the course and its periodicity.

Energy calculations, measured in joules (J or W·s) and ED $\left(\mathrm{J} / \mathrm{cm}^{2}\right.$ or $\left.\mathrm{W} \cdot \mathrm{s} / \mathrm{cm}^{2}\right)$ are not carried out, because this information is not necessary for effective laser therapy.

One of the general effect methods (laser acupuncture or ILIB) can be included into a laser therapy scheme as well as direct impact method on the affected area (local, transdermal or abdominal techniques, and also combined method - laser phoresis).

Local LILI exposure is carried out directly on the affected area, close to the body surface, or contact through a mirror head, or distantly, at a small distance from the surface $(1-2 \mathrm{~cm})$, stable. Sometimes associated physiotherapy method - magnetic laser therapy (MLT) is used, effecting through an opening of a permanent magnet with induction of 35-50 $\mathrm{mT}$.

These types of LILI are most often used for local laser exposure:

- continuous LILI of red spectrum (635 nm), PD - 10$15 \mathrm{~mW} / \mathrm{cm}^{2}$,

- $\quad$ pulsed LILI of red spectrum (635 nm), PD - 4-5 W/ $\mathrm{cm}^{2}$, pulse duration of $100-150 \mathrm{~ns}$, frequency 80 $10000 \mathrm{~Hz}$

- $\quad$ pulsed infrared LILI (890-904 nm), PD - 8-10 W/ $\mathrm{cm}^{2}$, pulse duration of $100-150 \mathrm{~ns}$, frequency 80 $10000 \mathrm{~Hz}$.

Frequency for pulsed laser varies depending on desired effect: for regeneration and anti-inflammatory effect it is $80-150 \mathrm{~Hz}$, analgesia $-3000-10000 \mathrm{~Hz}$. There are up to $2-3$ local zones for one area, exposure to each is 2-5 minutes. A more than 5-minute exposure is not allowed.

Local LILI exposure on skin in projection of affected organ differs from surface illumination, because only pulsed infrared lasers are used, preferably matrix, providing a therapeutic effect to a depth of $15 \mathrm{~cm}$ : wavelength - 890$904 \mathrm{~nm}, \mathrm{PD}-8-10 \mathrm{~W} / \mathrm{cm}^{2}$, pulse duration - 100-150 ns, frequency $-80-10000 \mathrm{~Hz}$. When the frequency of pulsed lasers is increased, the average irradiation power increases proportionately, that allows to effect on deeper areas. There are up to 2-3 local zones for one area, exposure to each is $2-5$ minutes. A more than 5-minute exposure is not allowed.

Laser acupuncture is performed by a special acupunc- ture head designed to concentrate laser beam energy to an area 1-2 $\mathrm{mm}$ in diameter. Wavelength is $635 \mathrm{~nm}$ (red spectrum), modes are continuous or modulated, output power is $2-3 \mathrm{~mW}$, exposure to one corporal acupuncture point is 20-40 seconds, on auricular - 5-10 seconds.

Laser irradiation of blood has two techniques as options: intravenous or non-invasive (over venous, external, transdermal, transcutaneous). These are accordingly ILIB and non-invasive laser irradiation of blood (NLIB).

A continuous mode is always used for ILIB, exposure is carried out intravenously through special disposable sterile light guides with paracentetic needle. ${ }^{84}$ Different techniques using laser light of different spectrum that are applied for ILIB are:

ILIB-635 (wavelength - $635 \mathrm{~nm}$, red spectrum, power - 1.5-2 mW, exposure - 10-20 minutes) has a universal effect, a positive effect on immune system and trophic provision of tissue.

ILIB-525 (wavelength - $525 \mathrm{~nm}$, green spectrum, power - 1.5-2 mW, exposure - 7-8 minutes) is recommended for maximum enhancement of trophic provision of tissue.

UV laser irradiation of blood (ULIB, wavelength - 365 $\mathrm{nm}$ (or $405 \mathrm{~nm}$ ), power - 1.5-2 mW, exposure - 3-5 min) is preferable for correction of immune disorders as a result of illness or injury.

NLIB is carried out on large blood vessels (arteries or veins), close to lesion focus. Pulsed lasers are mostly used, preferably of red $(635 \mathrm{~nm})$ or infrared (890-904 nm) spectrum and matrix (8 laser diode) emitters, or, as an option, with a single laser and mirror head ${ }^{42}$ :

- pulsed LILI of red spectrum (635 nm), PD - 4-5 W/ $\mathrm{cm}^{2}$, pulse duration - 100-150 ns, frequency $-80 \mathrm{~Hz}$

- pulsed infrared LILI (890-904 nm), PD - 8-10 W/ $\mathrm{cm}^{2}$, pulse duration $-100-150 \mathrm{~ns}$, frequency $-80 \mathrm{~Hz}$ Frequency is fixed. Impact on symmetric zones is possible, exposure to each is 2-5 minutes. A more than 5-minute exposure is not allowed.

Laser phoresis is one of modern physico-pharmacological methods of combined effects of percutaneous LILI and medicine. As a result of LILI on the area where a biologically active substance (gel or aqueous solution) was preliminary applied, activation of its penetration through skin (pores and hair follicles) occurs. Such transcutaneous non-injectional way of bringing the substance is only possible for low molecular $(500 \mathrm{kDa})$ and hydrophilic compounds. $^{85}$

Parameters of the technique:

- continuous LILI of red spectrum (635 nm), PD - 10$15 \mathrm{~mW} / \mathrm{cm}^{2}$,

- continuous infrared LILI (780-790 nm), PD - 40-50 $\mathrm{mW} / \mathrm{cm}^{2}$,

- $\quad$ pulsed infrared LILI (890-904 nm), PD - 8-10 W/ $\mathrm{cm}^{2}$, pulse duration $-100-150 \mathrm{~ns}$, frequency $-80 \mathrm{~Hz}$. Frequency for pulsed lasers is not changed. There are up to 15-20 local zones in one area, exposure to each zone is 1-1.5 minutes, but not more than 20 minutes for the whole procedure.

Intracavitary laser therapy (endonasal, endo auricular, 
etc.) is the delivery of laser light energy to affected area, located in a natural cavity, through a special lightguide tool (optical fiber). The peculiarity of the method is the necessity of injection of most of the energy into the fiber with the following distribution inside along a predetermined indicatrix. PD cannot always be defined; therefore, power at nozzle entrance is set. These types are most often used for laser exposure:

- continuous LILI of red spectrum (635 nm), power 10-15 mW,

- pulsed LILI of red spectrum (635 nm), power 4-5 W, pulse duration $100-150 \mathrm{~ns}$, frequency of $80-150 \mathrm{~Hz}$,

- pulsed infrared LILI (890-904 nm), power 15-20 W, pulse duration 100-150 ns, frequency $80-150 \mathrm{~Hz}$.

For infrared LILI only quartz-polymer fiber should be used as polymer PMMA almost completely absorbs light with a wavelength of more than $830 \mathrm{~nm}$.

Intra-articular laser therapy. The method consists in puncture of a joint by a thin needle, through which articular cavity is filled with oxygen. Another joint puncture is performed by a needle with a wider lumen $(0.8 \mathrm{~mm})$ through which lightguide is connected to radiating head of ILIB device. Under control of glowing through skin spot, lightguide is applied to the affected area of a joint (upper introversion, in pterygoid ligament area) and illuminates each department of the joint within 2-5 minutes. 2-5 areas are affected within 1 procedure. Continuous LILI with wavelength $635 \mathrm{~nm}$ (red spectrum) is used, radiation power at working end of lightguide is $5-10 \mathrm{~mW}$. The procedure is repeated in 3-4 days. Total number of procedures is $4-6 .{ }^{86}$

All presented LILI techniques are widely used in Russia for treatment of musculoskeletal, nervous and cardiovascular systems diseases, diseases of ear, nose and throat, after injuries and surgery, in dermatology and cosmetology, in obstetrics and gynecology, urology and andrology, pulmonology and phthisiology, i.e. in almost all areas of modern clinical medicine.

Associated and combined laser therapy methods are being actively developed: magnetic laser therapy, laser phoresis, laser-vacuum massage, etc. The concepts of combining LILI with taking medicine of different groups were worked out, that helps to reduce medicamental doses and risk of antibiotic resistance, to increase the effectiveness of the treatment. We should also talk about different options of multifrequency laser therapy techniques, using a set of fixed, physiologically relevant frequencies and also biosynchronized frequencies, natural frequencies of physiological regulation of a patient received by hardware means. These topics deserve separate publications.

\section{Conclusion}

Fundamental knowledge and continuous study of processes occurring in the interaction of LLLT with living cells, biological tissues and human body, as well as huge long-term successful experience of practical application of LT in clinical practice, allow to say that in Russia laser therapy is on an unprecedented high level and there are significant prospects of development and improving its effectiveness. Unfortunately, overwhelming majority of scientific publications on the topic and clinical guidelines are published only in Russian and are not available for specialists from other countries.

\section{Ethical Considerations}

Not applicable.

\section{Conflict of Interests}

None to be declared.

\section{References}

1. Tunér J, Hode L. It's all in the parameters: a critical analysis of some well-known negative studies on lowlevel laser therapy. J Clin Laser Med Surg. 1998;16(5):245-248.

2. Ohshiro T. Light and life: a review of low reactive-level laser therapy, following 13 year's experience in over 12000 patients. Laser Ther. 1993;5(1):5-22.

3. Zhou YC. LLLT in the people's republic of China. Laser Ther. 1991;3(1):5-9.

4. McKibbin LS, Downie R. LLLT in Canada. Laser Ther. 1991,3(1):45-47.

5. Baxter GD, Bell AJ, Allen JM, Ravey J. Low level laser therapy: current clinical practice in Northern Ireland. Physiotherapy. 1991;77(3):171-8.

6. Lap VC, Duet TC, Cuong DK. Low-level laser therapy: the experience in Vietnam. Laser Ther. 1994;6(1):62.

7. Ailioaie C, Chiran DA, Ailioaie LM. Laser blood irradiation in juvenile idiopathic arthritis - case study. Conference WALT; Lemesos, Cyprus; 2006. 181.

8. Korepanov VI. State of the art of laser therapy in Russia: a brief overview [Russian]. Laser Ther. 1997;9(1):41-42.

9. Skobelkin O. Achievements low level laser therapy in Russia [Russian]. Laser Ther. 1994;6(1):12.

10. Maiman TH. Stimulated optical radiation in ruby. Nature. 1960;187:493.

11. Mester E, Ludani G, Selyei M, Szende B, Total GJ. The stimulating effect of low power laser rays on biological systems. Laser Rev. 1968;1:3-8.

12. Mester E, Ludany G, Sellyei M, Szende B, Gyenes G, Total GJ. Studies on the inhibiting and activating effects of laser beams [German]. Langenbecks Archiv fur Chirurgie. 1968;322:1022-7.

13. Mester E, Ludany G, Sellyei M, Szende B. On the biologic effect of laser rays [German]. Bull Soc Int Chir. 1968;27(1):68-73.

14. Rounds DE, Chamberlain EC, Okigaki I. Laser radiation of tissue cultures. Ann N Y Acad Sci. 1965;28(122):713-27.

15. Geusic JE, Marcos HM, Van Uitert LG. Laser oscillations in ND-doped yttrium aluminum, yttrium gallium and gadolinium garnets. Appl Phys Letters. 1964;4(10):182.

16. Abergel RP, Meeker CA, Dwyer RM, Lesavoy MA, Uitto J. Nonthermal effects of Nd:YAG laser on biological functions of human skin fibroblasts in culture. Lasers Surg Med. 1984;3(4):279-84.

17. Castro DJ, Abergel RP, Meeker CA, Dwyer RM, Lesavoy MA, Uitto J. Effect of the Nd:YAG laser on DNA synthesis and collagen production in human skin fibroblast cultures. Ann Plastic Surg. 1983;11(3):214-22.

18. Franken PA, Ward JF. Optical harmonics and nonlinear phenomena. Rev Mod Phys. 1963;35(1):23-39. 
19. Rounds DE, Olson RS, Johnson FM. The laser as a potential tool for cell research. J Cell Biol. 1965;27 (1):191-197.

20. Patel CKN. Continuous-wave laser action on vibrational-rotational transitions of CO2. Phys Rev. 1964;136(5A):A1187-A1193.

21. Astafieva OG, Panchenkova GF, Gorbatenko EA. General interaction of laser irradiation with organs and tissues [Russian]. Saratov: Saratov University press; 1980:38-51.

22. Koshelev VN, Tarkhov GN, Astafieva OG, et al. Some problems of wound healing stimulation [Russian]. Materials of all-Union. conf. "The use of methods and means of laser technology in biology and medicine". Kiev: Naukova dumka; 1981:37-40.

23. Javan A, Bennett WR Jr, Herriott DR. Population inversion and continuous optical maser oscillation in a gas discharge containing a He-Ne mixture. Phys Rev Letters. 1961;6(3):106-113.

24. Inyushin VM. On the question of biological activity of red radiation [Russian]. Alma Ata; 1965:22

25. Inyushina TF, Inyushin VM. About the action of laser light on erythropoiesis [Russian]. Nekotoryye voprosy teoreticheskoy i prikladnoy biologii. Alma-Ata; 1967:1135.

26. Silfvast WT. Efficient CW laser oscillation at $4416^{\circ} \mathrm{A}$ in $\mathrm{Cd}$ (II). Appl Phys Letters. 1968;13(5): 169-71.

27. Shchur VV, Morozova VA, Shapiro AM, et al. Mathematical analysis of biological effect of helium-cadmium optical quantum generator in experiment on animals [Russian]. Gigiyenicheskiye aspekty ispol'zovaniya lazernogo izlucheniya v narodnom khozyaystve. Moscow; 1982:120122.

28. Hall RN, Fenner GE, Kingsley JD, Soltys TJ, Carlson RO. Coherent light emission from GaAs junctions. Phys Rev Letters. 1962;9(9):366-8.

29. Niels Ryberg Finsen - Facts. Nobelprize website. Nobel Media AB; 2014. http://www.nobelprize.org/nobel_prizes/ medicine/laureates/1903/finsen-facts.html.

30. Finsen NR. Om Anvendelse i Medicinen af Koncentrerede Kemiske Lysstraaler. Copenhagen, Denmark: Gyldendalske Boghandels Forlag; 1896:5-52.

31. Finsen NR. Ueber die Anwendung von concentrirten chemischen Lichtstrahlen in der Medicin. Leipzig: FCW Vogel; 1899:52.

32. Finsen NR. Light therapy [Russian]. St. Petersburg; 1901:39.

33. Bang S. Om fordelingen af bakteriedrøbende straaler i kulbuelysets spektrum. Meddeleleser fra Finsens Medicinske Lysinstitut.1904;IX:123-135.

34. Bie V. Om Lysets virkning paa Bakterier, Eksperimentielle Undersøgelser. Copenhagen, Denmark: Gyldendalske Boghandels Forlag; 1903:43-178.

35. Bie V. Use of light in medicine[Article in Russian]. St.Petersburg: "Prakticheskaya meditsina" (V.S. Ettinger); 1906.

36. Rieder H. Light Therapy [Russian]. St. Petesburg: magazine edition "Prakticheskaya meditsina" (V.S. Ettinger); 1902.

37. Rieder H. Luft- und Lichttherapie. 1911.

38. Moskvin SV. Laser therapy like a modern stage of heliotherapy (historical aspect) [Russian]. Lasernaya meditsina. 1997;1(1):44-49.

39. Moskvin SV. Laser therapy in dermatology: Vitiligo[Russian]. Tekhnika, Moscow; 2003.

40. Moskvin SV. Systemic analysis of the effectiveness of management of biological systems by low-energy laser irradiation [Thesis]. Tula; 2008.

41. Moskvin SV. The effectiveness of laser therapy. Series "Effective laser therapy" V. 2. [Russian]. Moscow-Tver: Triada; 2014.

42. Moskvin SV, Nasedkin AN, Kochetkov VA, et al. Therapy by Matrix Pulsed Lasers of Red Spectrum[Russian]. Tver: Triada; 2007.

43. Al-Watban FAH, Zhang XY. Comparison of the effects of laser therapy on wound healing using different laser wavelengths. Laser Ther. 1996;8(2):127-135.

44. Al-Watban FAH, Zhang XY. Comparison of wound healing process using argon and krypton lasers. J Clin Laser Med Surg. 1997;15(5):209-215.

45. Karu T. Photobiological fundamentals of low power laser therapy. IEEE Journal of Quantum Electronics. 1987;23(10):1703-1717.

46. Karu TI, Kalendo GS, Letokhov VS, Lobko VV. Biostimulation of HeLa cells by low intensity visible light. IL Nuovo Cimento D. 1982;1D(6):828-840.

47. Karu TI, Kalendo GS, Letokhov VS, Lobko VV. Biostimulation of HeLa cells by low intensity visible light. II. Stimulation of DNA and RNA synthesis in a wide spectral range. IL Nuovo Cimento. 1984;3D(2):309-318.

48. Karu TI, Kalendo GS, Letokhov VS, Lobko VV. Biostimulation of HeLa cells by low intensity visible light. III. Stimulation of nucleic acid synthesis in plateau phase cells. IL Nuovo Cimento. 1984;3D(6):319-325.

49. Karu T. Activation of metabolism of nonphotosynthesizing microorganisms with monochromatic visible (laser) light: A critical review. Lasers Life Sci. 1996;7(1):11-33.

50. Karu T. Ten lectures on basic science of laser phototherapy. Grängeberg, Sweden: Prima Books AB; 2007.

51. Karu TI. Mitochondrial signaling in mammalian cells activated by red and near-IR radiation. Photochem Photobiol. 2008;84(6):1091-1099.

52. Karu TI, Kolyakov SF. Exact action spectra for cellular responses relevant to phototherapy. Photomed Laser Surg. 2005;23(4):355-361.

53. Hamblin MR, Demidova TN. Mechanisms of low level light therapy. http://photobiology.info/Hamblin.html.

54. Smith KC. Laser and led photobiology. Laser Ther. 2010;19(2):72-78. doi:10.1089/pho.2005.23.78.

55. Hale GM, Querry MR. Optical constants of water in the 200 $\mathrm{nm}$ to $200 \mu \mathrm{m}$ wavelength region. Appl Opt. 1973;12:555563.

56. Berridge MJ, Lipp P, Bootman MD. The versatility and universality of calcium signaling. Nature Rev Mol Cell Biol. 2000;1(1):11-21.

57. Huang YY, Chen ACH, Carroll JD, Hamblin MM. Biphasic dose response in low level light therapy. Dose Response. 2009;7(4):358-383.

58. Zharov VP, Karu T, Litvinov J, Yu O, Tiflova OA. Photobiological effect of semiconductor laser irradiation in the near IR-area. Kvantovaya Elektronika. 1987,14(11):2135-2136.

59. Karu T, Tiphlova O, Esenaliev R, et al. Two different mechanisms of low-intensity laser photobiological effect on Escherichia coli. J Photochem Photobiol B. 1994;24(2):155161.

60. Nussbaum EL, Lilge L, Mazzulli T. Effects of 630-, 660-, $810-$, and $905-\mathrm{nm}$ laser irradiation delivering radiant exposure of $1-50 \mathrm{~J} / \mathrm{cm}^{2}$ on three species of bacteria in vitro. J Clin Laser Med Surg. 2002;20(6):325-333. 
61. Podshibyakin DV. Study of in vitro and in vivo morphophysiological characteristics of Escherichia coli and Staphylococcus aureus under action of low-intensity irradiation in visible and radio range [Thesis] [Russian]. Saratov; 2010.

62. Walker JB, Swartzwelder HS, Bondy SC. Suppression of hippocampal epileptiform activity in vitro after laser exposure. Laser Ther. 2005;14(2):19-21.

63. Rigau J, Sun CH, Trelles MA, Berns MW. Effects of the 633-nm laser on the behavior and morphology of primary fibroblast culture. SPIE Proceedings. 1996;2630:38-42.

64. Lubart R, Friedmann H, Sinyakov M, et al. The effect of $\mathrm{HeNe}$ laser $(633 \mathrm{~nm})$ radiation on intracellular $\mathrm{Ca}^{2+}$ concentration in fibroblasts. Laser Ther. 1997;9(3):115-20.

65. Lubart R, Friedmann H, Sinyakov M, et al. The effect of $\mathrm{HeNe}$ laser $(633 \mathrm{~nm})$ radiation on intracellular $\mathrm{Ca} 2+$ concentration in fibroblasts. Laser Ther. 2005;14(2):35-40.

66. Yu HS, Chang KL, Yu CL, Chen JW, Chen GS. Low-energy helium-neon laser irradiation stimulates interleukin-1 alpha and interleukin-8 release from cultured human keratinocytes. J Invest Dermatol. 1996;107(4):593-596.

67. Hemvani N, Chitnis DS, Bhagwanani NS. Effect of heliumneon laser on cultured human macrophages. Laser Ther. 1998;10(4):159-164.

68. Ribeiro MS, da Costa DR, Prates RA, et al. Study of the light parameters on cell cultures following low intensity red laser therapy. Conference WALT; Bergen, Norway; 2010:38.

69. Løvschall H, Scharff O, Foder B, Arenholdt-Bindslev D. Effect of low level laser irradiation on cytosolic $\mathrm{Ca}^{2+}$ in human neutrophils in vitro. Laser Ther. 1994,6(1):31.

70. Loevschal H, Arenholt-Bindslev D. Effect of low level diode laser irradiation of human oral mucosa fibroblasts in vitro. Lasers Surg Med. 1994;14(4):347-54.

71. Ferreira MPP, Ferrari RAM, Gravalos ED, Martins MD, Bussadori SK, Gonzalez DAB. Effect of low-energy galliumaluminum-arsenide and aluminium gallium indium phosphide laser irradiation on the viability of $\mathrm{C} 2 \mathrm{C} 12$ myoblasts in a muscle injury model. Photomed Laser Surg. 2009,27(6):901-906. doi: 10.1089/pho.2008.2427.

72. Yang HQ, Wang YH, Chen JX, et al. Efficacy of proliferation of HeLa cells under three different low-intensity red lasers irradiation. Int J Photoenergy. 2012;2012:290796:5. doi:10.1155/2012/290796.

73. Alexandratou E, Yova D, Handris P, Kletsas D, Loukas S. Human fibroblast alterations induced by low power laser irradiation at the single cell level using confocal microscopy. Photochem Photobiol Sci. 2002;1(8):547-552.

74. Breibart H, Levinshal, Cohen N, Friedmann H, Lubart $\mathrm{R}$. Changes in calcium transport in mammalian sperm mitochondria and plasma membrane irradiated at $633 \mathrm{~nm}$ (HeNe laser). J Photochem Photobiol B. 1996;34(2-3):117121.

75. Colver GB, Priestley GC. Failure of a helium-neon laser to affect components of wound healing in vitro. Br J Dermatol. 1989;121(2):179-186.

76. Friedmann H, Lubart R. Photobiostimulation by lightinduced cytosolic calcium oscillations. Laser Ther. 1996;8(2):137-141.

77. Lubart R, Friedman H, Sinuakov M, Cohen N, Breibart $\mathrm{H}$. Change in calcium transport in mammalian sperm mitochondria and plasma membranes caused by $780-\mathrm{nm}$ irradiation. Lasers Surg Med. 1997;21(5):493-499.

78. Smith KC. Light and life: photobiological basis of the therapeutic use of radiation from lasers. In: Selected papers from the October 1990 ILTA Congress "Progress in laser therapy". Oshiro T, Calderhead RG, eds. Chichester, England: John Wiley \& Sons; 1990:11-18.

79. Webb C, Dyson M, Lewis WH. Stimulatory effect of 660$\mathrm{nm}$ low level laser energy on hypertrophic scarderived fibroblasts: possible mechanisms for increase in cell counts. Laser Surg Med. 1998,22(5):294-301.

80. Breitbart H, Wehbie R, Lardy H. Regulation of calcium transport in bovine spermatozoa. Biochim Biophys Acta. 1990;1027(1):72-78.

81. Singh JP, Babcock DF, Lardy HA. Motility activation, respiratory stimulation, and alteration of $\mathrm{Ca}^{2+}$ transport in bovine sperm treated with amine local anesthetics and calcium transport antagonists. Arch Biochem Biophys. 1983;221(1):291-303.

82. Tombes RM, Borisy GG. Intracellular free calcium and mitosis in mammalian cells: anaphase onset is calcium modulated, but is not triggered by a brief transient. J Cell Biol. 1989;109(2):627-636.

83. Mester E, Mester AF, Mester A. The biomedical effects of laser application. Lasers Surgd Med. 1985;5(1):31-39.

84. Geinitz AV, Moskvin SV. New technologies of intravenous laser irradiation of blood: "ILIB+ULIB" and "ILIB-405" [Russian]. Tver: Triada; 2010.

85. Moskvin SV, Minenkov AA, Konchugova TV. Mechanisms of action of percutaneous laser phoresis with hyaluronic acid, justification of optimal procedure parameters [Russian]. Plasticheskaya khirurgiya i kosmetologiya. 2011;3:519-24

86. Tupikin GV. Use of low-energy laser irradiation (argon with $\lambda=488 \mathrm{~nm}$ and helium-neon with $\lambda=632 \mathrm{~nm}$ ) in treatment of patients with rheumatoid arthritis [Thesis] [Russian]. Moscow; 1984. 